\title{
Ambroży Skorupa
}

Przyczyny i procedura wydalania duchownych $\mathrm{z}$ instytutu zakonnego

Prawo Kanoniczne : kwartalnik prawno-historyczny 54/3-4, 147-168

2011

Artykuł został opracowany do udostępnienia w internecie przez Muzeum Historii Polski w ramach prac podejmowanych na rzecz zapewnienia otwartego, powszechnego i trwałego dostępu do polskiego dorobku naukowego i kulturalnego. Artykuł jest umieszczony w kolekcji cyfrowej bazhum.muzhp.pl, gromadzącej zawartość polskich czasopism humanistycznych i społecznych.

Tekst jest udostępniony do wykorzystania w ramach dozwolonego użytku. 


\section{KS. AMBROŻY SKORUPA SDS}

Katolicki Uniwersytet Lubelski Jana Pawła II w Lublinie

\section{PRZYCZYNY I PROCEDURA WYDALENIA DUCHOWNYCH Z INSTYTUTU ZAKONNEGO}

Treść: Wstęp. - 1. Przyczyny wydalenia. - 1.1. Naruszenie doktryny katolickiej. - 1.2. Naruszenie dobrych obyczajów. - 1.2.1. Usiłowanie zawarcia małżeństwa. - 1.2.2. Konkubinat. -1 .2.3. Inny zewnętrzny grzech przciwko szóstemu przykazaniu dekalogu. - 1.2.4. Przestępstwa przeciwko życiu i wolności człowieka. - 1.3. Przestępstwa przeciw dyscyplinie zakonnej. - 1.3.1. Permanentne naruszanie obowiązków życia konsekrowanego. - 1.3.2. Powtarzające się naruszanie świętych więzów - ślubów zakonnych. - 1.3.3. Uporczywe nieposłuszeństwo prawnym nakazom przełożonych w poważnej materii. - 1.3.4. Bezprawna nieobecność trwająca pół roku. - 1.3.5. Wielkie zgorszenie powstałe wskutek zawinionego zachowania się członka. - 1.3.6. Inne podobne poważne przyczyny, określone ewentualnie własnym prawem instytutu. -2 . Procedura. -2.1 . Wydalenie ipso facto -2.2 . Wydalenie obligatoryjne. -2.2 .1 . Wydalenie w przypadku delicta graviora. -2.3 . Wydalenie fakultatywne. -3 . Skutki prawne wydalenia. -4 . Ocena procedury. - Zakończenie.

\section{Wstęp}

Życie duchownych w instytucie zakonnym wymaga odpowiednich standardów. Prawo kościelne wymaga, aby do święceń dopuszczać tylko tych, którzy cieszą się dobrą opinią. Wraz z wymaganiami do święceń trzeba też uwzględnić wymagania stawiane kandydatom do życia zakonnego. Złożenie profesji wieczystej i przyjęcie sakramentu święceń wymaga sposobu życia i pełnienia posługi w taki sposób, aby budować lud Boży, aby wzrastała wiara wiernych. Odpowiedni przykład duchownych żyjących zgodnie z duchem życia zakonnego oraz $z$ charakterem swojego instytut jest ubogaceniem Kościoła.

Z kolei niepowodzeniem dla Kościoła, instytutu i samego duchownego zakonnego jest okoliczność, kiedy standardy życia zakonnego 
i duchownego są naruszone. Powstaje wtedy zgorszenie, obniżenie życia duchowego wiernych, szkoda dla wspólnoty Kościoła. Wobec takich zagrożeń władza zakonna jest zobowiązana reagować. Jedną z możliwości normatywnych, jaką prawo kościelne daje przełożonym jest wydalenie z instytutu. Jest to poważna kara, która sprawia, że ustają skutki złożonej profesji zakonnej jak również zabronione jest wykonywanie władzy święceń. Stwierdzenie bądź wymierzenie takiej kary może mieć miejsce z poważnych przyczyn, których zaistnienie należy udowodnić zgodnie z obowiązującymi procedurami. Regulacje dotyczące zarówno przyczyny wydalenia jak i obowiązujące procedury będą treścią tego artykułu.

\section{Przyczyny wydalenia}

Wydalenie z instytutu zakonnego może mieć wiele przyczyn. Związane jest zawsze z postawą zakonnika-duchownego. Przyczyny wydalenia możemy podzielić na te związane z głoszoną doktryną, jeśli jest niezgodna z nauczaniem Kościoła, przyczyny moralne dotyczące pewnych gorszących zachowań. W tej części zostanie wrócona uwaga na postawy gorszące związane z naruszeniem przykazań Bożych i kościelnych, jak również przepisów KPK 1983. Kolejne przyczyny wydalenia wynikają z niezachowania obowiązków wynikających z życia konsekrowanego oraz przynależności do konkretnego instytutu zakonnego.

\subsection{Naruszenie doktryny katolickiej}

Do przestępstw, które są naruszeniem doktryny katolickiej KPK 1983 zalicza: notoryczne odstąpienie, rozpowszechnianie poglądów potępionych przez Urząd Nauczycielski Kościoła, od wiary katolickiej i publiczne przyjęcie ideologii przepojonych materializmem i ateizmem. Popełnienie tych przestępstw zagrożone jest karą wydalenia z instytutu zakonnego także dla jego duchownych członków.

W kan. 694 czytamy, że na skutek popełnienia samego faktu (ipso facto) z instytutu zakonnego wydalony jest ten, kto notoryczne odstąpił od wiary katolickiej. W prawie kanonicznym rozróżniamy notoryczność faktyczną i prawną. Przestępstwo jest notoryczne, jeżeli w żaden sposób nie można go ukryć ani usprawiedliwić, dlatego przed sądem nie wymaga dowodu. Przestępstwo może być notorycznie prawne lub faktyczne. O przestępstwie prawnie notorycznym mówimy 
wtedy, gdy zostało stwierdzone wyrokiem sądowym, który przeszedł w stan rzeczy osądzonej ${ }^{1}$. Sytuacja, kiedy oskarżony przyzna się przed trybunałem do popełnienia przestępstwa, czy to z własnej inicjatywy czy odpowiadając na pytanie sędziego - takie przestępstwo również jest uznane za prawnie notoryczne. Przestępstwo jest faktycznie notoryczne, jeżeli czyn przestępczy jest publiczne znany i nie można go ukryć. Pewna są także: poczytalność sprawcy, jego intencja i wola popełnienia przestępstwa. Dla społeczności i władzy kościelnej fakt jest powszechnie znany a sprawca nie może się usprawiedliwić obroną konieczną ani inną okolicznością łagodzącą ${ }^{2}$.

Formy odstąpienia od wiary katolickiej są następujące: apostazja, herezja, schizma, wstapienie do akatolickiej sekty. Kan. 751 - Herezja nazywa sięuporczywe, po przyjęciu chrztu, zaprzeczanie jakiejś prawdzie, $w$ którq należy wierzyć wiarq boskq i katolicka, albo uporczywe powatpiewanie o niej; apostazja-catkowite porzucenie wiary chrześcijańskiej, schizma - odmowa uznania zwierzchnictwa Biskupa Rzymskiego lub utrzymywania wspólnoty z członkami Kościoła, uznajacymi to zwierzchnictwo. Łacińskie brzmienie kanonu 751: schisma, subiectionis Summo Pontifici aut communionis cum Ecclesiae membris eidem suditis detrectatio, zakazuje więc utrzymywania wspólnoty z członkami Kościoła, którzy zaprzeczają (detrectatio, detrecto), że papież jest zwierzchnikiem Kościoła ${ }^{3}$.

Kolejną przyczyną wydalenia duchownych z instytytutu zakonnego ze względu na niezachowanie doktryny jest podtrzymywanie lub rozpowszechnianie poglądów potępionych przez Nauczycielski Urząd Kościoła. Ta ogólna norma jest zawarta w kan. 696.

KPK 1983 używa sformułowania: diffisio doctrinarum ab Ecclesiae magisterio damnatarum. Na uwage zasługuje termin damnatarum od słowa damnatus, a,um-potępiony a $\mathrm{a}^{4}$. Odnosząc się do różnych poglądów,

1 KPK 83 Kan. 1641-1642.

2 CIC 1917 Kan. 2197. F. Bączkowicz, J. Baron, W. Stawinoga, Prawo Kanoniczne. Podręcznik dla duchowieństwa, t. 3, wyd. 3, Wydawnictwo Diecezjalne św. Krzyża w Opolu 1958 s. 352-353; B. Zubert, Komentarz do Kodeksu Prawa kanonicznego, t. 2 cz. III, Redakcja Wydawnictw KUL, Lublin 1990, s. 220.

3 Detrectatio - odmowa, wzbranianie się, ociąganie; detrecto - odmówić, zaprzeczyć. Zob. A. Jougan, Stownik kościelny łacińsko-polski, Wyd. 3, WarszawaPoznań-Lublin 1958, s. 191; także Sondel, Słownik łacińsko-polski dla prawników i historyków, Kraków 1997, s. 279.

${ }^{4}$ Damnatus - potępiony, skazany, zbrodniczy - A. Jougan, Słownik, s. 172. 
Kongregacja Nauki Wiary takiego terminu nie użyła już dość dawno. Analizując dokumenty Kongregacji Nauki Wiary można powiedzieć, że używa się tam terminów: niezgodne z doktryna katolicka, nie do zaakceptowania $w$ świetle katolickiej doktryny, jest moralnie niegodziwe, moralnie niedopuszczalne, niedozwolone jest, konieczne jest przeciwstawienie się, tezy te głęboko sprzeczne z wiarq chrześcijańska itp. Urząd Nauczycielski Kościoła wyraził swoje negatywne stanowisko wobec poglądów zarówno doktrynalnych jak i ocen moralnych. Jeśli chodzi o dokumenty doktrynalne, to można egzemplarycznie wskazać następujące wypowiedzi Kongregacji Nauki Wiary: nota na temat książki Jacques'a Dupuis «Ku chrześcijańskiej teologii pluralizmu religijnego», w której czytamy: Błędna jest natomiast opinia, jakoby te elementy prawdy $i$ dobra lub też niektóre $z$ nich nie wyptywaty $w$ istocie rzeczy ze źródłowego pośrednictwa Jezusa Chrystusa ${ }^{5}$. Kolejnym stanowiskiem wyrażonym przez Kongregację Nauki Wiary jest treść nauczania o Jezusie Chrystusie, jako Synu Bożym: ...Powyższe tezy sq głęboko sprzeczne z wiara chrześcijańska. Należy bowiem , stanowczo wyznać naukę wiary", która głosi, że to Jezus z Nazaretu, Syn Maryii tylko On-jest Synem i Słowem Ojca. Słowo, które „, byto na poczatku u Boga” (J 1,2), jest tym samym, które , stało się ciałem” $(J 1,14)$. W Jezusie „Mesjaszu, Synu Boga żywego (Mt 16,16) „,mieszka cała petnia: Bóstwo na sposób ciała” (Kol 2,9). On jest „Jednorodzonym Bogiem, który jest w tonie Ojca” (J 1,18), Jego ,umiłowanym Synem, w którym mamy odkupienie - odpuszczenie grzechów (... $)^{6}$.

W życiu chrześcijańskim szczególną wartość ma modlitwa. Wszystkie spotkania modlitewne powinny odbywać się zgodnie z doktryną i formą przedstawioną przez Kościół. Stanowisko Kongregacji Nauki Wiary w sprawie modlitwy o uzdrowienie jest następujące: ...Zatem, w spotkaniach modlitewnych zorganizowanych celem prośby o uzdrowienie, bytoby niedopuszczalne przypisywanie ,charyzmatu uzdrawiania”

5 Kongregacja Nauki Wiary, Nota z dnia 24 stycznia 2001 na temat ksiażki Jacques'a Dupuis, «Ku chrześcijańskiej teologii pluralizmu religijnego», Ed. Queriniana, Brescia 1997, http://www.vatican.va/roman_curia/congregations/cfaith/ documents/rc con cfaith doc 20010124 dupuis pl.html

${ }^{6}$ Kongregacja NauKI Wiary, Deklaracja o jedyności i powszechności zbawczej Jezusa Chrystusa i Kościoła Dominus Jesus, AAS 92 (2000) 742-765; http:// www.vatican.va/roman_curia/congregations/cfaith/documents/rc_con_cfaith_doc_ 20000806_dominus-iesus_pl.html 
pewnej kategorii uczestników, na przykład kierownikom grupy. Nie pozostaje nic innego, jak zawierzyć suwerennej woli Ducha Świętego, który daje pewnym osobom specjalny charyzmat uzdrawiania, aby ukazać moc łaski Zmartwychwstałego. Tymczasem nawet najżarliwsze modlitwy nie sprawiq uzdrowienia $z$ wszystkich chorób ${ }^{7}$.

Prymat władzy papieża jest znaczącą doktryną na temat ustroju Kościoła. W historii istniało wiele różnych poglądów, które albo kwestionowały albo podważały pozycję następcy św. Piotra. Dlatego Kongregacja Nauki Wiary przypomniała stanowisko Kościoła w tej sprawie:

Przypomnienie to pomoże również uniknać istniejacej zawsze możliwości ponownego pojawienia się interpretacji czastkowych i jednostronnych, już w przeszłości odrzuconych przez Kościót-febronianizm, gallikanizm, ultramontanizm, koncyliaryzm ${ }^{8}$.

Uporczywe głoszenie przez duchownego zakonnika jednego z wyżej wymienionych poglądów lub innego odrzuconego przez Urząd Nauczycielski Kościoła może być przyczyną wydalenia zakonnika, także duchownego z instytutu.

Kolejny blok tematów, na który wypowiedziała się Kongregacja Nauki Wiary dotyczy poglądów katolika na kwestie moralne. Wypowiedzi te dotyczą takich kwestii jak: zapłodnienie in vitro, eutanazja, aborcja, ocena zachowań homoseksualnych czy legalizacja związków homoseksualnych.

W sprawie zapłodnienia in vitro Kościół zajmuje negatywne stanowisko. Akceptowanie bezkrytyczne takiego zapłodnienia przyczynia się do osłabienia świadomości i szacunku należnego każdej istocie ludzkiej. Technika, która powoduje całkowite oddzielenie prokreacji od aktu ludzkiego jest moralnie niegodziwa.

${ }^{7}$ Kongregacja NaUKI Wiary, Instrukcja na temat modlitw $w$ celu osiagnięcia uzdrowienia pochodzqcego od Boga z 14 września 2000, L'Osservatore Romano, 24 listopada 2000, s. 6.

8 Kongregacja Nauki Wiary, Prymat nastepcy Piotra w tajemnicy Kościoła. Uwagi Kongregacji Nauki Wiary, Communicationes 30 (1998) 207-216, http://www.vatican.va/ roman_curia/congregations/cfaith/documents/rc_con_cfaith_doc_19981031_primatosuccessore-pietro_pl.html. 
Podobne stanowisko zajmuje Kościół w temacie zapobiegana aborcji. Aborcja embrionu dopiero co zagnieżdżonego, stosowanie środków przeciwciwciążowych jest poważnie niemoralne ${ }^{9}$.

Moralny i prawny aspekt postaw homoseksualnych był w Kościele podejmowany wielokrotnie. Zachowania homoseksualne są niedopuszczalne i grzeszne. Natomiast głoszenie poglądów, że zachowania i postawy są uzasadnione z katolickiego punktu widzenia są niedopuszczalne. Kongregacja Nauki Wiary wypowiadała się na ten temat w kontekscie ogólnym, jak również w kontekście głoszenia poglądów przez niektóre osoby zakonne. W kontekście ogólnym trzeba wskazać wypowiedź na temat legalizacji związków homoseksualnych. Od katolika wymaga się postawy sprzeciwu wyrażonego w sposób jasny ${ }^{10}$. Moralna ocena zachowań homoseksualnych wypowiadana przez osobę zakonną powinna być zgodna z oceną Kościoła. Doktrynalnie nie do zaakceptowania jest nauczanie, które nie ukazuje wewnętrznego zła czynów homoseksualnych ${ }^{11}$.

Kolejnym obszarem, który Kongregacja Nauki Wiary poddaje ocenie moralnej jest eutanazja. Życie ludzkie należy szanować od poczęcia do naturalnej śmierci. Należy stosować podstawową opiekę i stosować środki, dzięki którym życie będzie podtrzymane. Niedozwolone jest jej przerwanie albo niestosowanie, jeśli konsekwencja takiej decyzji byłaby śmierć pacjenta. Byłaby to eutanazja przez zaniechanie ${ }^{12}$.

$\mathrm{Na}$ temat aborcji, usunięcia poczętego życia Kościół również wypowiadał się wieloktrotnie. Bardzo wyraźne jest nauczanie papieża

${ }^{9}$ Kongregacja NaUKI Wiary, Instrukcja Dignitas personae z dnia 8 września 2008 dotycząca niektórych problemów bioetycznych, AAS 100 (2008) 858-887; http:// www.vatican.va/roman_curia/congregations/cfaith/documents/rc_con_cfaith_doc_ 20081208_dignitas-personae_pl.html.

${ }^{10}$ Kongregacja NaUKI Wiary, Uwagi dotyczqce projektów legalizacji zwiazków między osobami homoseksualnymi z 3 czerwca 2003. http://www.vatican.va/roman curia/congregations/cfaith/documents/rc_con_cfaith_doc_20030731_homosexualunions pl.html

11 Kongregacja Nauki Wiary, Informacja dotyczqca siostry Jeannine Gramick i Księdza Roberta Nugent SDS, AAS 91 (1991) s. 821-825. Tekst polski, W trosce o pełnię wiary. Dokumenty Kongregacji Nauki Wiary 1995-2000, s. 66-69.

12 Jan Paweł II, Przemówienie do grupy biskupów amerykańskich $w$ czasie wizyty ad limina 2 października 1998 roku, w: Kongregacja Nauki Wiary, Odpowiedzi na pytania dotyczące sztucznego odżywiania i nawadniania z 1 sierpnia 2007, http:// www.vatican.va/roman_curia/congregations/cfaith/documents/rc_con_cfaith_doc_ 20070801 risposte-usa_pl.html 
Jana Pawła II w encyklice Evangelium vitae, gdzie papież mówi o odrażajacej zbrodni przerywania ciaży. Jasno jest przedstawione stanowisko, że nie ma takich racji, które usprawiedliwiałyby umyślne pozbawienie życia niewinnej istoty ludzkiej ${ }^{13}$. Niedopuszczalne jest też usprawiedliwienie przerywania ciąży. Kościół zawsze nauczał i naucza, że owoc ludzkiej prokreacji od pierwszego momentu swego istnienia ma prawo do bezwarunkowego szacunku, jaki należy się ludzkiej istocie ${ }^{14}$. Życie ludzkie jest święte i nienaruszalne w każdej chwili swego istnienia ${ }^{15}$. Znaczenie ma także ocena moralna przerywania ciąży, która jest wielkim nieładem moralnym. W ten sposób zobowiązny jest oceniać aborcję duchowny członek instytutu zakonnego ${ }^{16}$.

Do poglądów potępionych przez urząd nauczycielski Kościoła należą także ideologie przepojone materializmem i ateizmem. Materializm jest uznawany za zło na równi z bałwochwalstwem, odstępstwem lub wszelkim nieposłuszeństwem przykazaniom Bożym w materii ciężkiej ${ }^{17}$. Ateizm z kolei został odrzucony w nauczaniu Soboru Watykańskiego II ze względu na fakt, że nie odpowiada wolności i godności osoby ludzkiej ${ }^{18}$. Przyjęcie ideologii ateistycznej lub materialistycznej może dokonać się w wymiarze zewnętrznym jak i intelektualnym. Materializm natomiast, jako stanowisko doktrynalne, jest odrzucany wraz z relatywizmem i panteizmem ${ }^{19}$. Postawa oraz głoszenie tych ideologii jest poważnym zagrożeniem dla ludu Bożego, ponieważ może prowadzić do apostazji ${ }^{20}$.

Notoryczne odstapienie od wiary katolickiej uporczywe głoszenie poglądów potępionych przez Urząd Nauczycielski Kościoła oraz przyjęcie ideologii przepojonych materializmem i ateizmem jest zagrożone sankcją wydalenia z instytutu zakonnego.

13 Evangelium vitae 58.

14 Evangelium vitae 60.

15 Evangelium vitae 61.

16 Evangelium vitae 62.

17 Veritatis splendor 70.

18 Fides et ratio 60.

19 Fides et ratio 80.

${ }^{20}$ M. BIDER, Wydalenie fakultatywne z instytutu zakonnego wedtug Kodeksu Prawa Kanonicznego, Wydawnictwo KUL, Lublin 2006, s. 76-77. 


\subsection{Naruszenie dobrych obyczajów}

Od duchownych członków instytutu zakonnego wymaga się odpowiednich postaw moralnych. Naruszanie tych standardów może być dyskwalifikujace ze stanu zakonnego i duchownego. Tymi dyskwalifikującymi zachowaniami są: usiłowanie zawarcia małżeństwa, choćby tylko cywilnego, życie w konkubinacie, wolnym związku lub w innym zewnętrznym grzechu przeciw szóstemu przykazaniu dekalogu.

\subsubsection{Usiłowanie zawarcia małżeństwa}

Norma kan. 694 n. 2 stanowi, że z mocy samego prawa jest wydalony z instytutu zakonnego ten, kto zawarł małżeństwo, usiłował je zawrzeć choćby tylko cywilne. Duchowny zakonny nie może zawrzeć ważnego małżeństwa, ponieważ jest związany przeszkodą ślubu i przeszkodą święceń ${ }^{21}$. Jeśli miałby miejsce fakt zawarcia przez niego małżeństwa kanonicznego czy cywilnego, takie małżeństwo byłoby małżeństwem nieważnym i usiłowanym. $Z$ małżeństwem usiłowanym mamy do czynienia wtedy, kiedy zgoda małżeńska została wyrażona, natomiast jedna ze stron miała świadomość, że małżeństwo zawiera nieważnie ${ }^{22}$. Przestępstwo usiłowanie zawarcia małżeństwa ma miejsce wtedy, kiedy zostaje wyrażona zgoda małżeńska. Przed urzędowym wyrażeniem zgody nie można mówić o małżeństwie usiłowanym, o którym jest mowa w kan. 1394, lecz o konkubinacie albo innym wolnym związku, o których normy są zawarte w kanonie $1395^{23}$. Konsekwencją prawną usiłowania zawarcia małżeństwa jest wydalenie $\mathrm{z}$ instytutu zakonnego mocą samego prawa ${ }^{24}$ oraz kara suspensy, również z mocy samego pra-

${ }^{21}$ Zgodnie z normą kan. 1052§ 2 dymisorie dla kandydata do święceń, który jest członkiem instytutu życia konsekrowanego i stowarzyszenia życia apostolskiego powinny wyraźnie zaświadczać, że kandydat został definitywnie włączony do instytutu.

${ }_{22}^{2}$ V. De Paolis, Obblighi speciali, delitti contro, Delitto di attentato matrimonio, Nuovo Dizionario di Diritto Canonico, red. C. Salvador, V. DE Paolis, G. Girlanda, Torino 1996, s. 726.

23 J. Arias, Code de droit canonique bilingue et annoté, $3^{\mathrm{e}}$ edition 2007 sous la direction de E. Caparros et H. Aubé avec la collaboration de J. I. Arrieta et D. LE Tourneau, Montreal 2008, s. 1718-1719; B. Zubert, Komentarz do Kodeksu Prawa kanonicznego z 1983 r., t. 2 cz. III, Redakcja Wydawnictw KUL, Lublin 1990, s. 220 222.

24 Kan. 694. 
$\mathrm{wa}^{25}$. Wydalenie i suspensa następują z chwilą popełnienia przestępstwa usiłowania zawarcia małżeństwa ${ }^{26}$.

\subsubsection{Konkubinat}

Konkubinat jest związkiem mężczyzny i kobiety, trwający określony czas a nieuregulowany prawnie. Od małżeństwa nieważnego, usiłowanego różni się tym, że w przypadku konkubinatu nie ma woli zawarcia małżeństwa ${ }^{27}$. Do konkubinatu nie jest wymagane zamieszkanie razem. O konkubinacie możemy mówić już wtedy, kiedy jest utrzymywany stały kontakt odznaczający się systematycznością i dłuższym czasem. Duchowny zakonny konkubinariusz powinien być wydalony z instytutu, czego wymagają normy kan, 695 i 1395. W kan. 694 tym zawarte jest stwierdzenie sodales dimitti debet-członek powinien być wydalony, które to obliguje przełożonego, aby wydalił zakonnika $\mathrm{z}$ instytutu.

\subsubsection{Inny zewnętrzny grzech przciwko szóstemu} przykazaniu dekalogu

Jako przyczyny wydalenia obligatoryjnego należy wskazać także inne zewnętrzne grzechy przeciw szóstemu przykazaniu dekalogu. Zaliczany do nich faktyczne wolne związki. Wolne związki faktyczne to takie, w których osoby żyją razem bez formalnego powiązania. Aby mówić o istnieniu wolnego związku potrzebny jest czas kilku miesięcy ${ }^{28}$.

Oprócz konkubinatu i wolnych związków KPK 1983 w kan. 1395 jest wymienione takie wydarzenie jak inny zewnętrzny grzech przeciw szóstemu przykazaniu dekalogu. Grzech ten musi być więc zewnętrzny. Jego zewnętrzny wymiar, możliwość udowodnienia jego istnienia obliguje przełożonego do wydalenia z instytutu. Grzechy przeciwko szóstemu przykazaniu dekalogu są wskazane w Katechiźmie Kościoła

${ }^{25}$ Kan. 1394.

26 Zubert, Komentarz, s. 219.

27 E. Szczot, Skutki kanoniczne pozostawania katolika w zwiazku niesakramentalnym, w: Kościelne Prawa Procesowe. Materiały i studia, t.3 red. A. DzIĘGA, M WróBel, Lublin 2003, s. 115.

28 E. Szczot, Skutki kanoniczne, s. 112-113. 
Katolickiego. Według niego można wskazać: rozwiqzłość ${ }^{29}$, nierzad ${ }^{30}$, pornografię ${ }^{31}$, korzystanie z prostytucji ${ }^{32}$ i gwatt ${ }^{33}$.

Kolejnym grzechem zewnętrznym przeciw szóstemu przykazaniu dekalogu wyrażonym w przepisie kan. 1395 są także zachowania homoseksualne czy to te wynikające z kultury gejowskiej czy przy okoliczności okazajonalnej postawy homoseksualnej ${ }^{34}$. Taką postawę również należy ocenić, jako inny, zewnętrzny grzech przeciw szóstemu przykazaniu dekalogu, wywołujący zgorszenie.

Zewnętrznym grzechem może być podjęcie innych czynności seksualnych. Takie określenie spotykamy w polskim kodeksie karnym. Inna czynność seksualna to wszelkie zachowania o wyrazie seksualnym i intencji, które nie są obcowaniem płciowym. W rozumieniu $197 \S 2$ kodeksu karnego konieczny jest cielesny kontakt uczestników takiego czynu lub przynajmniej cielesne i o charakterze seksualnym zaangażowanie ofiary (np. dotykanie narządów płciowych ofiary, zmuszanie jej do onanizowania innej osoby, do obnażania czy onanizowania się, wykonywania określonych cielesnych manipulacji seksualnych ${ }^{35}$.

Zewnętrznym grzechem przeciwko szóstemu przykazaniu dekalogu jest także udział w rozpowszechnianiu pornografiii tej drukowanej i czy elektronicznej. Polskie prawo karne uznaje prezentowanie treści pornograficznych, narzucanie tych treści innej osobie, która sobie tego nie

${ }^{29}$ KKK 2351: Rozwiazłość jest nieuporządkowanym pożądaniem lub nieumiarkowanym korzystaniem z przyjemności cielesnych.

${ }^{30}$ KKK 2353: Nierzad jest zjednoczeniem cielesnym między wolnym mężczyzną i wolną kobietą poza małżeństwem.

31 KKK 2354: Pornografia polega na wyrwaniu aktów płciowych, rzeczywistych lub symulowanych, z intymności partnerów, aby w sposób zamierzony pokazywać je innym.

32 KKK 2355: Prostytucja narusza godność osoby, która oddaje się prostytucji, stając się przedmiotem przyjemności cielesnej kogoś drugiego.

33 KKK 2356: Gwatt oznacza wtargnięcie przemocą w intymność płciową osoby.

34 Zob. Kongregacja EduKacj KatolickieJ, Instrukcja n.t. kryteriów rozeznawania powołania u osób z tendencjami homoseksualnymi ubiegajacych się o przyjęcie do seminariów i dopuszczania do święceń, 4 XI 2005, „L'Osservatore Romano” (wyd. pol.) nr 5/2006, s. 54-56; Kongregacja Instytutów Życia KonseKrowanego i StowarzysZeŃ Życia Apostolskiego, Potissum institutioni z dnia 2 lutego 1990 r., AAS 82 (1990) 470-532, tekst polski w: Życie konsekrowane w dokumentach Kościoła, oprac. B. Hylla CR Kraków 1998 s. 297- 348 n. 13.

${ }_{35}$ Prawo karne materialne. Część ogólna i szczególna, red. BoJARSKI MareK, GiezeK JaceK, Sienkiewicz Zofia, Wydawnictwo LexisNexis 2010, s. 444-445. 
życzy; produkowanie, utrwalanie, sprowadzanie, przechowywanie lub posiadanie za przestępstwo podlegające karze. Przestępstwo to normuje art. 202 kodeksu karnego, którego popełnienie jest zagrożone karą grzywny, ograniczenia lub pozbawienia wolności ${ }^{36}$.

Popełnienie jednego z wyżej wymienionych przestępstw jest podstawą do obligatoryjnego wydalenia $\mathrm{z}$ instytutu.

Normy kanonów 695 i 1395 wymienią także jako zewnętrzny grzech przeciw szóstemu przykazaniu dekalogu inną czynność przeciw szóstemu przykaniu z użyciem przymusu. O doprowadzaniu do obcowania płciowego lub innych czynności seksualnych przemocą, bezprawną groźbą, podstępem czytamy w kodeksie karnym. Czynności te są zakazane także z punktu widzenia prawa państwowego ${ }^{37}$.

W kan. 1395 czytamy także o przestępstwie przeciw szóstemu przykazaniu dekalogu z osobą małoletnią. Za przestępstwo z osobą małoetnią należy zakonnika duchownego wydalić z instytutu. Osobami

${ }^{36}$ Ustawa z dnia 6 czerwca 1997 r. Kodeks postępowania karnego, Dz. U. z dnia 4 sierpnia $1997 \mathrm{r}$.

Art.202. §1. Kto publicznie prezentuje treści pornograficzne w taki sposób, że może to narzucić ich odbiór osobie, która tego sobie nie życzy, podlega grzywnie, karze ograniczenia wolności albo pozbawienia wolności do roku.

$\S 2$. Kto małoletniemu poniżej lat 15 prezentuje treści pornograficzne lub udostępnia mu przedmioty mające taki charakter albo rozpowszechnia treści pornograficzne w sposób umożliwiający takiemu małoletniemu zapoznanie się z nimi, podlega grzywnie, karze ograniczenia wolności albo pozbawienia wolności do lat 2.

$\S 3$. Kto w celu rozpowszechniania produkuje, utrwala lub sprowadza, przechowuje lub posiada albo rozpowszechnia lub publicznie prezentuje treści pornograficzne $\mathrm{z}$ udziałem małoletniego.

$\S 4$. Kto utrwala treści pornograficzne z udziałem małoletniego poniżej lat 15 , podlega karze pozbawienia wolności od roku do lat 10 .

$\S 4$ a. Kto sprowadza, przechowuje lub posiada treści pornograficzne z udziałem małoletniego poniżej lat 15 .

37 Art. 197. § 1. Kto przemocą, groźbą bezprawną lub podstępem doprowadza inną osobę do obcowania płciowego.

$\S 2$. Jeżeli sprawca, w sposób określony w $§ 1$, doprowadza inną osobę do poddania się innej czynności seksualnej albo wykonania takiej czynności,

§ 3. Jeżeli sprawca dopuszcza się zgwałcenia wspólnie z inną osobą,

Art. 198. Kto, wykorzystując bezradność innej osoby lub wynikający z upośledzenia umysłowego lub choroby psychicznej brak zdolności tej osoby do rozpoznania znaczenia czynu lub pokierowania swoim postępowaniem, doprowadza ją do obcowania płciowego lub do poddania się innej czynności seksualnej albo do wykonania takiej czynności, 
małoletnimi w rozumieniu ustawodawstwa kanonicznego, są ci którzy nie ukończyli 18 roku życia ${ }^{38}$. W kodeksie karnym ten wiek jest ustalony na 15 rok życia. W przypadku popełnienia przestępstwa z osobą małoletnią należy zastosować procedurę regulowaną Sacramentorum sanctitatis tutela. Według kodeksu karnego przestępstwem jest obcowanie płciowe z nieletnim, inna czynność seksualna z taką osobą, prezentowanie małoletniemu wykonanie czynności seksualnej39.

\subsubsection{Przestępstwa przeciwko życiu i wolności człowieka}

Przestępstwami przeciwko życiu i wolności są: zabójstwo, zranienie, okaleczenie porwanie z użyciem siły lub podstępu. Do tej grupy przestępstw zalicza się także aborcja. Nauka Kościoła dotycząca moralnej doktryny została omówiona wyżej ${ }^{40}$. W kan. 1398 czytamy, że kto powoduje zerwanie ciaży, po zaistnieniu skutku podlega ekskomunice wiażacej moca samego prawa. Zgodnie z nauczaniem papieża Jana Pawła II, takiej ekskomunice podlega każdy, kto pozytywnie współpracuje i przyczynia się do aborcji ${ }^{41}$. Odwołanie się w kan. 695 do kan. 1397 i 1398 zobowiąuje przełożonego zakonnego do wydalenia duchownych, którzy współpracowali na rzecz aborcji.

\subsection{Przestępstwa przeciw dyscyplinie zakonnej}

Obowiązki życia konsekrowanego dotyczą także pewnych praktyk duchowych. Jeśli postawa lub zaniechanie będzie, poważne, zewnętrzne, poczytalne $i$ prawnie potwierdzone, wtedy może mieć miejsce wydalenie.

38 W kan. 1395 jest mowa o ukończeniu 16-go roku życia. Norma Sacramentorum sanctitatis tutela ustala ten wiek na 18 lat.

${ }^{39}$ Art. 200. § 1. Kto obcuje płciowo z małoletnim poniżej lat 15 lub dopuszcza się wobec takiej osoby innej czynności seksualnej lub doprowadza ją do poddania się takim czynnościom albo do ich wykonania,

podlega karze pozbawienia wolności od lat 2 do 12 .

$\S 2$. Tej samej karze podlega, kto w celu zaspokojenia seksualnego prezentuje małoletniemu poniżej lat 15 wykonanie czynności seksualnej.

40 Kan. 1397 i 1398.

${ }^{41}$ Evangelium vitae 62: Ekskomunika obejmuje wszystkich, którzy dopuszczają się tego przestępstwa, wiedząc, jaką jest obłożone karą, a więc także tych współsprawców, bez których udziału to przestępstwo nie zostałoby popełnione. 


\subsubsection{Permanentne naruszanie obowiązków życia konsekrowanego}

Obowiązki życia konsekrowanego to: życie wspólnotowe, praktyki ascetyczne, praktyki sakramentalne - sakrament pokuty co $15 \mathrm{dni}^{42}$, Eucharystii $^{43}$, uczestniczenie w corocznych rekolekcjach ${ }^{44}$, odmawianie liturgii godzin ${ }^{45}$, zachowanie klauzury ${ }^{46}$. Przedstawiając w sposób bardzo ogólny obowiązki życia konsekrowanego należy zwrócić uwagę na obowiązek powstrzymania się od tego, co nie przystoi stanowi zakonnemu i duchownemu ${ }^{47}$. Duchowni zakonni nie powinni więc przyjmować publicznych urzędów, podejmować transakcji bez zgody kompetentnej władzy, zaciaggać się do wojska, wstępować do parti politycznych oraz związków zawodowych, podejmować zadań obcych stanowi duchownemu. Jako duchowni, także członkowie instytutów zakonnych zobowiązani są powstrzymywać się od takich postaw. Permanentne i powodujące zgorszenie naruszanie tych obowiązków bądź zakazów może być przyczyną wydalenia fakultatywnego.

\subsubsection{Powtarzające się naruszanie świętych więzów - ślubów zakonnych}

W instytutach zakonnych składa się tylko śluby, to jedyne święte więzy. Ich permanentne naruszanie może być przyczyną wydalenia fakultatywnego. Ślub jest dobrowolną obietnicą złożoną samemu Bogu, mającą za przedmiot dobro możliwe i lepsze ${ }^{48}$. W kontekście życia zakonnego śluby trzech rad ewangelicznych są istotnym elementem profesji zakonnej ${ }^{49}$. Materią świętych więzów są rady ewangeliczne - czystości, ubóstwa i posłuszeństwa. Materia czystości, przestępstw i grzechów zewnętrznych przeciw szóstemu przykazaniu dekalogu zostały opisane wyżej. W tym punkcie można podkreślić materię ślubu posłuszeństwa i ubóstwa. Sposób praktyki rad ewangelicznych jest regulowany w konstytucjach. Praktykowanie rady ubóstwa zobowiązuje do życia pracowitego, w trzeźwości, z dala od ziemskich bogactw.

\footnotetext{
42 Kan. 664.

43 Kan. $663 \S 2$.

44 Kan. $663 \S 5$.

45 Kan. $663 \S 3$.

46 Kan. 667.

47 Kan. 285 .

48 Kan. $1191 \S 1$.

49 Kan. 654.
} 
Dysponowanie i administrowanie dobrami materialnymi również jest regulowane prawem własnym instytutu ${ }^{50}$.

Kolejnym obszarem omawianego punktu jest ślub posłuszeństwa. Praktyka tej rady zobowiązuje do podporządkowania własnej woli prawowitym przełożonym, zastępującym Boga, gdy wydają polecenia zgodnie z własnymi konstytucjami. Uporczywe naruszanie, kwestionowanie przedstawionej doktryny rady posłuszeństwa jest również przyczyną wydalenia duchownego z instytutu zakonnego ${ }^{51}$.

\subsubsection{Uporczywe nieposłuszeństwo prawnym nakazom przełożonych w poważnej materii}

Kompetencje i decyzje przełożonych obligują do ich wykonania. Do władzy należy ostatnie słowo jak również zadbanie o to, aby podjęte decyzje zostały zrealizowane ${ }^{52}$. Uporczywe nieposłuszeństwo oznacza zachowanie pomimo upomnień, nakazów i zakazów przełożonych. Przełożeni działają w imieniu Boga kiedy wydają decyzje zgodnie z konstytucjami. Poważna materia nieposłuszeństwa będzie więc dotyczyła tych decyzji przełożonych, które są regulowane w prawie własnym. Prawne nakazy mogą wydawać przełożeni różnych stopni - zarówno przełożeni wyżsi jak i przełożeni lokalni.

50 Kan. 600.

51 Kongregacja Instytutów Życia Konsekrowanego I Stowarzyszeń Życia Apostolskiego., Instrukcja Faciem tuam Domine requiram, Libreria Editrice Vaticana, Watykan 2008; B. Szewczul, Ewangeliczna rada postuszeństwa $w$ posłudze przełożonego zakonnego, w: Ewangeliczna rada posłuszeństwa w życiu konsekrowanym zakonnym a wolność osoby. Materiały z Ogólnopolskiej Konferencji Naukowej UKSW, Warszawa 21 października 2009, red. W Kiwior, J. KrajczyŃsKi, H. Stawniak, Wydawnictwo Uniwersytetu Kardynała Stefana Wyszyńskiego, Warszawa 2010, s. 65 85; A. SKorupa SDS, Postuszeństwo zakonne wżyciu ,podwładnego” W: Ewangeliczna rada postuszeństwa $w$ życiu konsekrowanym zakonnym a wolność osoby, Materiały z Ogólnopolskiej Konferencji Naukowej UKSW, Warszawa 21 października 2009, red. W. Kiwior, J. KrajCZYŃsKi, H. StawniaK, Wydawnictwo Uniwersytetu Kardynała Stefana Wyszyńskiego, Warszawa 2010, s. 87-108; A. SKorupa SDS, Sprawowanie władzy zakonnej wedtug „Faciem tuam, Domine, requiram”. Studia Salvatoriana Polonica, t. 4, s. 209-220.

52 Vita consecrata 43. 


\subsubsection{Bezprawna nieobecność trwająca pół roku}

Zakonnik jest zobowiązany przebywać we własnym domu zakonnym. Dom ten można opuścić za zgodą przełożonego ${ }^{53}$. Prawodawca przewiduje także okoliczności, które usprawiedliwiają wydanie pozwolenia na pobyt poza domem zakonnym nieobecość. Przełożony wyższy za zgodą rady może zezwolić na pobyt poza domem zakonnym do okresu jednego roku. Dłuższy pobyt poza domem zakonnym jest uzasadniony ratowaniem zdrowia, studiami oraz wykonywniem apostolatu w imieniu instytutu. Domu zakonnego nie można opuszczać bez pozwolenia przełożonego. To pozwolenie dotyczy zarówno opuszczenia domu jak i czasu tej nieobecności. Nieobecność bezprawna, to taka, na którą nie wyraził zgody przełożony, trwająca pół roku ${ }^{54}$ i jest przestępstwem, za które może zakonnik duchowny być wydalony $\mathrm{z}$ instytutu ${ }^{55}$.

\subsubsection{Wielkie zgorszenie powstałe wskutek zawinionego zachowania się członka}

Bardzo ogólna norma zawarta w kan. 696, wskazująca, że przyczyną wydalenia może być także jakiekolwiek zachowanie zakonnika, które powoduje wielkie zgorszenie. Chodzi o zgorszenie powstałe na skutek niewłaściwego zachowania, za które odpowiedzialny jest zakonnik duchowny. Można wskazać takie zachowanie niegodne zakonnika, które powoduje zgorszenie, winnym jego powstania jest zakonnik. Takie zachowanie może dotyczyć sfery ekonomicznej, czy obyczajowej.

\subsubsection{Inne podobne poważne przyczyny, określone ewentualnie własnym prawem instytutu}

Kolejna, w sposób bardzo ogólny wyrażona przyczyna wydalenia fakultatywnego. Przyczyna ta musi być równie poważna jak wyżej wymienione. Może ona ewentualnie być regulowana w prawie własnym instytutu. Fakt, czy przyczyna ta będzie określona w prawie własnym czy nie, nie będzie miała wpływu na możliwość wydalenia. Można wskazać na takie zachowanie duchownego zakonnika, które nie jest

53 Kan. 665. M. BILSKa CSSJ, Obowiqzek zamieszkania zakonnika we własnym domu zakonnym, Msp. Lublin 2010, s. 255-259.

54 Por. kan. $395 \$ 4$.

55 Por. Kan. 695 i 665. 
zgodne z charyzmatem instytutu, jego duchowością czy celem. Jak wszystkie wyżej wymienione przyczyny wydalenia muszą być powazne, zewnętrzne, poczytalne i prawnie potwierdzone $e^{56}$.

\section{Procedura}

Procedura wydalenia $\mathrm{z}$ instytutu zakonnego jest określona w normach KPK 1983. Przełożony zakonny jest zobligowany do zachowania procedury. Zastosowanie tej procedury zależy od rodzaju przestępstw popełnionych przez duchowwnego zakonnika. Kodeks obowiązujacy przewiduje za niektóre przestępstwa karę wydalenia $\mathrm{z}$ powodu faktu popełnienia przestęptwa (ipso facto), za niektóre wydalenie obligatoryjne a za niektóre wydalenia fakultatywne.

\subsection{Wydalenie ipso facto}

W przypadku przestępstw normowanych w kan. 694 duchowny zakonny zostaje wydalony na skutek popełnionego czynu. W takim przypadku przełożony jest zobowiązany zebrać dowody, aby potwierdzić fakt odstapienia od wiary katolickiej usiłowania zawarcia małżeństwa.

Notoryczne odstapienie od wiary katolickiej dokonuje się zgodnie z przepisami prawa. kościelnego $\mathrm{W}$ tym przypadku konieczne jest udokumentowanie, że zakonnik - duchowny wystapił z Kościoła katolickiego, lub wstapił do niekatolickiej grupy wyznaniowej. Potwierdzeniem takiego faktu jest dokument sporządzony przez kompetentną władzę kościelną lub wiarygodne świadectwa osób, które wiedzą o łączności zakonnika duchownego z akatolicką grupą religijną ${ }^{57}$. Kolejnym dokumentem może być wyrok sądu, który potwierdzi apostazję, schizmę lub herezję zakonnika duchownego. Wydalenie z instytutu następuje z chwilą odstąpienia od wiary katolickiej.

Najbardziej przekonującym dowodem wydaje się przedstawienie od byłego podwładnego skróconego odpisu z Urzędu Stanu Cywilnego. Ten dokument stanowi obiektywne potwierdzenie faktu zawarcia kontraktu cywilnego. Zakomunikowanie, że duchowny zakonny usiłował

56 Zob. kan. 696.

57 Z. Tracz, Przynależność do Kościoła Katolickiego, w: 25-lecie promulgacji Kodeksu Prawa Kanonicznego. Obowiązywanie i stosowanie w Polsce, red.: J. Krukowski, Z. Tracz, Łódź 2009, s. 201-225; W. Wenz, Apostazja i formalny akt wystapienia z Kościoła. Zasady postępowania $w$ świetle norm kościelnych, Studia Salvatoriana Polonica, t. 4, s. 129-152. 
zawrzeć małżeństwo, choćby tylko cywilne albo informacja że zawarł kontrakt cywilny jest równoznaczne $\mathrm{z}$ oświadczeniem, że został on wydalony $z$ instytutu na mocy samego prawa. Wydalenia następuje $\mathrm{z}$ datą usiłowania zawarcia małżeństwa.

Jeśli okaże, że niemozliwe jest otrzymanie dokumentu potwierzającego usiłowanie zawarcia małżeństwa, wtedy można sięgnąć po dowody pośrednie. Opinie wiarygodnych świadków, wspólne zamieszkanie, nazwisko dzieci uczęszczających do szkoły czy na katechezę mogą być dowodem na zawarcie małżeństwa cywilnego. Chociaż są to dowody pośrednie, ich uzyskanie może trwać dłuższy czas, jednak wydalenie następuje z chwilą zawarcia małżeństwa cywilnego.

Po zebraniu dowodów przez przełożonego przełożony jest zobowiązany stwierdzić zainstnienie faktu zawarcia małżeństwa lub notorycznego odstapienia od wiary katolickiej. Po stwierdzeniu takiego faktu zakonnik duchowny został wydalony z instytutu na mocy samego prawa.

\subsection{Wydalenie obligatoryjne}

Wydalenie obligatotoryne jest obowiązkiem władz zakonnych na skutek popełnionych przestępstw. Według normy kan. 695 przestępstwa te zostały wymienione w kan 1395, 1397 i 1398. Procedura wydalenia obligartoryjnego wymaga od przełożonego wyższego zebrania dowodów odnośnie do faktów i poczytalności oskarżonego. Gromadzeniem i oceną dowodów zobowiązany jest zająć się przełożony wyższy. Do wykonania tego zadania może on wyznaczyć także inną odpowiednią osobę, zgodnie z kan. $1717 \S 1$. Kolejnym krokiem przełożonego jest zakomunikowanie oskarżonemu o stawianych mu zarzutach i przedstawienie dowodów. Zebranie dowodów należy tak przeprowadzić, aby nikt nie poniósł szkody podczas dochodzenia ${ }^{58}$. Do akt sprawy należy włączyć także dokumenty zawierające odpowiedzi oskarżonego oraz argumenty jego obrony. Prawo wymaga, aby działania przełożonego były udokumentowane i podpisane akta przez przełożonego wyższego i notariusza należy przesłać do najwyższego przełożonego ${ }^{59}$. Najwyższy przełożony wraz ze swoją radą, która powinna składać się z minimum 4 członków powinien przystąpić do rozważenia dowodów.

\footnotetext{
58 Kan. $1717 \S 2$.

59 Kan. 697.
} 
Decyzja o wydaleniu z instytutu zostaje podjęta w kolegialnym głosowaniu, po którym przełożony najwyższy wydaje dekret wydalający. W dekrecie należy przedstawić argumenty faktyczne i prawne uzasadniające wydalenie ${ }^{60}$. Kolejnym etapem jest przesłanie dekretu do zatwierdzenia kompetentnej władzy hierarchicznej. W przypadku instytutu na prawie diecezjalnym jest to biskup dieczji zamieszkania zakonnika, zgodnie z kan. 103; natomiast w przypadku instytutu na prawie papieskim jest to Stolica Apostolska. Jeśli dekret zostanie potwierdzony, wtedy może nastąpić notyfikacja - urzędowe powiadomienie o wydaleniu. Do ważności tego dekretu należy informacja, że wydalony ma dziesięć dni od chwili otrzymania informacji na złożenie rekursu hierarchicznego do Kongregacji Instytutów Życia Konsekrowanego i Stowarzyszeń Życia Apostolskiego. Wniesienie rekursu powoduje zawieszenie dekretu. Potwierdzenie dekretu oraz upływ dziesięciu dni od otrzymania dekretu powoduje wydalenie z instytutu.

\subsubsection{Wydalenie w przypadku delicta graviora}

W przypadku przstępstwa przeciw szóstemu przykazaniu Dekalogu, popełnionego przez duchownego zakonnika z osobą nieletnią poniżej osiemnastego roku życia, ordynariusz zakonny po otrzymaniu wiadomości, przynajmniej prawdopodobnej, powinien rozpocząć wstępne badanie. Po przeprowadzeniu tego badania wstępnego winien powiadomić o tym Kongregację Nauki Wiary, która wskaże ordynariuszowi sposób postępowania. Wydalenie następuje po udowodnieniu przestępstwa i wydania stosownego dekretu ${ }^{61}$.

\subsection{Wydalenie fakultatywne}

Procedura wydalenia fakultatywnego regulowana jest w kan. 697. Przełożony wyższy, po otrzymaniu informacji o popełnieniu przestępstwa powinien wszcząc proces o wydalenie. Sam, lub przez inną odpowiednią osobę powinien zebrać i uzupełnić dowody. Następnym etapem jest upomnienie kanoniczne wysłane do oskarżonego. W tym upomnieniu powinno być wyraźnie zaznaczone, że jeśli postawa duchownego zakonnika nie zmieni się, wtedy przełożony podej-

\footnotetext{
60 Kan. 699.

${ }^{61}$ Jan Paweł II. List apostolski motu proprio Sacramentorum sanctitatis tutela, AAS 93 (2001) 737-739.
} 
mie procedurę wydalenia $\mathrm{z}$ instytutu. Wobec postawionych zarzutów i ostrzeżeń poniesienia konsekwencji karnych, oskarżony musi mieć możliwość obrony. Jeśli upomnienie okazało się nieskuteczne, po piętnastu dniach należy skierować drugie upomnienie. Po wysłaniu drugiego bezskutecznego upomnienia przełożony wyższy wraz ze swoją radą przystępuje do oceny oskarżenia. Jeśli przełożony wraz z radą uznają fakty, że niepoprawne postępowanie zakonnika duchownego jest pewne, obrona niewystarczajaca, wtedy należy przesłać wszystkie akta podpisane przez notariusza do przełożonego generalnego, jak w przypadku wyżej opisanego wydalenia obligatoryjnego. Przełożony generalny podejmuje decyzję wraz z radą i przesyła dekret wydalenia do Stolicy Apostolskiej.

\section{Skutki prawne wydalenia}

Przez prawne wydalnie ustają prawa i obowiązki wynikające z profesji. Duchowni wydaleni z instytutu zakonnego nie mogą wykonywać władzy święceń. Zgodnie z kan. 701 duchowny wydalony z instytutu zakonnego nie może wykonywać władzy święceń. Duchowny taki jest bowiem w karze sysupensy, która zabrania mu wykonywania wszystich aktów władzy święceń ${ }^{62}$. Wydalenie $\mathrm{z}$ instytutu i zakaz wykonywania władzy święceń nie zobowiązuje jednak więzów inkardynacji z instytutem ${ }^{63}$. Członek instytutu zakonnego zostaje inkardynowany do instytutu przyjmując święcenia diakonatu. Trwające, mimo wydalenia, więzy inkardynacji zobowiązują ordynariusza zakonnego do przeprowadzenia procesu dyspensowania od przeszkody celibatu i innych obowiązków wynikających ze święceń ${ }^{64}$. Podstawą takiej normy są trwające więzy inkardynacji.

W przypadkach takich przestępstw popełnionych przez duchownych zakonnych jak: usiłowanie zawarcia małżeństwa, choćby tylko

${ }^{62}$ Kan. 1333 - $§ 1$. Suspensa, która może być stosowana jedynie do duchownych, zabrania:

$1^{\circ}$ wszystkich lub tylko niektórych aktów władzy święceń; zob. M. BIDER, Wydalenie fakultatywne, s. 168-169.

63 J. Beyer, La dimissione nella vita consacrata, w: Procedimenti speciali nel diritto canonico, Città del Vaticano 1992, s. 337-356; M. BIDER, Wydalenie fakultatywne, s. 170.

${ }^{64}$ Kongregacja NaUKI Wiary, Normy dyspensowania od celibatu kapłańskiego. Normy proceduralne, art. 1, tekst polski: W trosce o pełnię wiary. Dokumenty Kongregacji Nauki Wiary 1966-1994, s. 68-71; (AAS 72 (1980) 1136-1137. 
cywilnego, przestępstwa apostazji, herezji lub schizmy, jak suspensa jest karą mocą samego prawa dla duchownych ${ }^{65}$.

Wykonywać władzę święceń może dopiero po zezwoleniu biskupa diecezjalnego, który przynajmniej zezwoli na wykonywanie święceń. W dalszym etapie może taki zakonnik zostać przyjęty na okres próby i inkardynowany do diecezji, zgodnie z przepisami kan. 693, 267 i 269. W przypadku wydalenia obligatoryjnego lub fakultatywnego zawieszenie wykonywania władzy święceń następuje z chwilą uprawomocnienia się dekretu. Wydalony z instytutu zakonnego duchowny nie może wykonywać władzy święceń. Ewentualne wykonywanie tej władzy może umożliwić decyzja życzliwego biskupa diecezjalnego, który po okresie próby może go inkardynować do diecezji.

Wydalenie z instytutu nie upoważnia wydalonych do otrzymania wynagrodenia czy restytucji za pracę wykonaną w instytucie. W intytucie mieszkali, mieli zapewnione wszystko, co jest potrzebne do prowadzenia działności zgodnej z duchem instytutu. Wydalony nie może się domagać wynagrodzenia ani restytucji, jednak instytut powinien zachować wobec wydalonych słuszność i ewangeliczną miłośćc6.

\section{Ocena procedury}

Procedura wydalenia duchownych $\mathrm{z}$ instytutu zakonnego jest jasno skonstruowana. Kompetencje są rozpisane bardzo precyzyjnie ${ }^{67}$. Jednak w niektórych punktach pojawiają się pewne watpliwości $\mathrm{w}$ odniesieniu do kościelnego prawa procesowego. Zgodnie z normą kan. 1448 sędzia nie powinien przyjmować sprawy, w której jest w jakiś sposób zainteresowany z powodu wielkiej zażyłości czy niechęci. Według tego prawa kan. 1449 oskarżony ma prawo wnioskować o wykluczenie ze składu sędziego, wobec którego miałby pewne zarzuty, czy wątpliwości. Oskarżony zakonnik może mieć zarzuty wobec przełożonego wyższego czy najwyższego albo któregoś z radnych. W obowiązujących normach nie ma możliwości wykluczenia ze składu decydujących o wydaleniu kogokolwiek. Można sobie wyobrazić

${ }^{65}$ Suspensa z mocy samego jest przewidziana w kan. 1370 §2, 1378 §2, kan. 1390 $\S 1,1394 \S 1$.

${ }^{66}$ Kan. 702; M. BIDER, Wydalenie fakultatywne, s. 186.

${ }^{67}$ Zob. A. SkorupA, Kompetencje wyższego przełożonego zakonnego i jego rady $w$ procesie wydalenia $z$ instytutu zakonnego, w: Kościelne prawo procesowe. Materiały i studia, t. 3, red. A. DziĘGA. M. Wróbel, Lublin 2003, s. 289-303. 
sytuację, kiedy oskarżony wykaże, że urzędujący przełożony wyższy, który kompletuje dowody przeciw niemu był, jeszcze niedawno, jego spowiednikiem lub kierownikiem duchowym. Taka sama sytuacja może dotyczyć także przełożonego najwyższego lub któregoś z członków jego rady. Zgodnie z kan.1550 wiadomości uzyskane w sakramencie pokuty nie mogą być uznane nawet jak ślad prawdy. Dlatego uzasdnionym byłoby wycofanie takiego radnego ze składu decydującego o wydaleniu ${ }^{68}$. Natomiast trudne do uzasadnienia byłoby usunięcie z tego składu najwyższego przełożonego. Istniejące normy nie dają jasnych podstaw do rozwiązania tego problemu. Zasadnym byłoby wprowadzenie zasady, że w sytuacji uzasadnionej zastępca przełożonego najwyższego przejmuje rolę przewodniczącego. Jeszcze bardziej uzasadnionym byłoby umożliwienie przełożonemu wyższemu powołania trybunału, który zajmowałby się wydaleniem.

\section{Zakończenie}

Duchowny zakonny w instytucie realizuje swoje powołanie podążając drogą właściwą dla charyzmatu instytutu. Postawa duchownego zakonnego niezgodna z powołaniem kapłańskim jak również z charyzmatem instytutu może być przyczyną wydalenia z instytutu zakonnego. Przyczynami wydalenia może być głoszenie doktryny niezgodnej z nauczaniem Urzędu Nauczycielskiego Kościoła, jak również przyjęcie postawy niezgodnej ze stanowiskiem Kościoła. W artykule przedstawiono egzemplarycznie wypowiedzi Kongregacji Nauki Wiary, które dotyczą kwestii doktrynalnych jak i moralnych. Uporczywe głoszenie pogladów uznanych przez Stolicę Apostolską za niezgodne z doktryną katolicka, uznanych przez Kościół za takie może być przyczyną wydalenia z instytutu. Wydalenie z instytutu zakonnego może być także konsekwencją postawy niezgodnej z dyscypliną kościelnąjak i zakonną. Postawy takie, są powodem poważnego skandalu wymagają reakcji ze strony kompetentnych przełożonych zakonnych. Przełożeni zobowiązani są działać zgodnie z procedurami, których normy są zawarte w KPK 1983 i innych dokumentach kościelnych. Podjęcie własciwej procedury jest uzależnione od tego z jakim przestępstwem duchownego zakonego mamy do czynienia. Za przestępstwa określone w kan. 694 zakonnik wydalony jest z mocy popełnionego czynu

68 Por. Kan.1448-1449. 
(ipso facto). W związku z tym trzeba zachować procedurę przepisaną w tym kanonie dla tej formy wydalenia. Inna jest procedura w okoliczności popełnionych przestępstw opisanych w kan. 695 i 1395, za popełnienie których ustawodawca przewidział wydalenie obligatoryjne. W sytuacji popełnionych przestępstw wskazanych w normie kan. 696 przełożony jest zobowiązany podjąć procedurę wskazaną w kan. 697. Na uwage zasługuje uprawnienie oskarżonego do obrony, udział notariusza w sprawie, podjęcie decyzji przez przełozonego najwyższego i zatwierdzenie dekretu przez kościelną władzę hierarchiczną - Stolicę Apostolską lub biskupa diecezjalnego, w zależności od stopnia zatwierdzenia instytutu.

\section{Causes and process for dismissal of members from religious institute}

A religious in an institute fulfills his vocation by following the way adequate to the charism of the institute. An attitude unsuited to a religious' priestly vocation as well as to the institute's charism, can be the cause of dismissal from religious institute. Among the causes of dismissal can be diffusion of doctrine inconsistent with the magisterium of the Church or an attitude incompatible with position of the Church. In the article were presented some exemplary statements of the Congregation for the Doctrine of the Faith regarding doctrinal and moral questions. Stubborn diffusion of views recognized by the Holy See as opposed to the Catholic doctrine, may be another cause for dismissal from an institute. Dismissal from religious institute may also result from an attitude incompatible with the ecclesiastical and religious discipline. Attitudes causing grave scandal require reaction of the competent religious superiors. The superiors are obliged to act in accordance with the process regulated by the norms included in the CCL 1983 and in other ecclesiastical documents. Choosing proper process depends on the nature of an offense committed by a religious. For offenses described in can. 694 a religious is dismissed by the fact itself of committing the offense (ipso facto). Therefore the process described in the cannon for this form of dismissal must be kept. In instances of offenses described in cannons 695 and 1395, for which the legislator provided an obligatory dismissal, the process is different. In case of offenses pointed out in can. 696 the superior is obliged to initiate process indicated in can. 697. The right of the accused to self-defense, participation of a notary in the process, required decision by the major superior and approval of a decree by ecclesiastical hierarchical authority - the Holy See or diocesan bishop, depending on the approval level of the institute, deserves attention. 